УДК 81’371'367.624

DOI https://doi.org/10.26661/2414-1135-2021-83-26

\title{
ЕКСПЛІКАЦІЯ ЛЕКСИЧНО ТА СЕМАНТИЧНО ОКАЗІОНАЛЬНИХ ІМЕННИКІВ 3 КОНОТАТИВНИМ УВИРАЗНЕННЯМ У МОВІ УКРАЇНСЬКОЇ ПРЕСИ
}

\author{
Мироненко О. В. \\ кандидат філологічних наук, \\ доиент кафедри теорії та методики дошкільної та початкової освіти \\ Херсонський державний університет \\ вул. Університетська, 27, Херсон, Україна \\ orcid.org/0000-0002-9775-6220 \\ mirok130581@gmail.com
}

\author{
Ключові слова: конотачія, \\ семантика, явище, іменник, \\ лексичні та семантичні \\ оказіоналізми, преса, \\ експлікація.
}

Конотація у статті репрезентується як лексико-семантичне явище, що увиразнюється складною термінологічною парадигмою, діалектичною структурною організацією та семантичною різноплановістю. Як лінгвістичний феномен конотація тісно пов'язана 3 інноваційними, історичними, прагматичними, аксіологічними модифікаціями у суспільстві. Узуально-оказіонально виражені лексеми репрезентують зміни у мовній картині світу, що виражають психологічні, екстралінгвальні, семіотичні ракурси реального/ірреального простору. Особливу увагу приділено узуально та оказіонально диференційним іменникам з конотативним значенням, які активно вживаються у мові української преси. До узуально різноаспектних іменників з конотативним значенням належать активно вживані, продуктивно функціональні лексичні одиниці. Під оказіонально диференційними іменниками 3 конотативним значенням розуміють такі, що поділяються на лексичні, у яких репрезентується нова форма та зміст лексеми, та семантичні, що характеризуються новою змістовою наповненістю, а їхня форма залишається незмінною. Виявлення значення лексично та семантично оказіональних іменників 3 конотативним увиразненням можливе завдяки: 1) підтекстовій потенційності, що допомагає розкрити суть та специфіку конотативного значення; 2) асоціативним реакціям, що спонукають до створення образної картини світу та експлікації семантичного потенціалу конотативно вираженої лексеми; 3) текстовим компонентам, які служать для вираження та передачі семантичного потенціалу іменників 3 конотативним увиразненням та можуть стояти у препозиції чи постпозиції до аналізованого слова; 4) лапкам, що виконують функцію розрізнення семантичного навантаження лексеми у певних контекстних ситуаціях; 5) семантичним модифікаціям, що характеризуються зміною значення у інформаційній контекстуальній площині, де розкривається конотативний потенціал аналізованого слова. Лексично та семантично оказіональні іменники з конотативним значенням у мові української преси фокусують та підкреслюють інновації, що відбуваються у всіх сферах буття. 


\title{
EXPLICATION OF LEXICALLY AND SEMANTICALLY OCCASIONAL NOUNS WITH CONNOTIVE EXPRESSION IN THE LANGUAGE OF THE UKRAINIAN PRESS
}

\author{
Mironenko O. V. \\ Candidate of Philological Sciences, \\ Associate Professor at the Department of Theory and Methods \\ of Preschool and Primary Education \\ Kherson State University \\ University str., 27, Kherson, Ukraine \\ orcid.org/0000-0002-9775-6220 \\ mirok130581@gmail.com
}

Key words: connotation, semantics, phenomenon, noun, lexical and semantic occasionalisms, press, explication.

\begin{abstract}
The connotation in the article is represented as a lexical-semantic phenomenon, which is expressed by a complex terminological paradigm, dialectical structural organization and semantic diversity. As a linguistic phenomenon, connotation is closely linked to innovative, historical, pragmatic, and axiological modifications in society. Occasionally expressed tokens represent changes in the linguistic picture of the world, expressing psychological, extralingual, semiotic perspectives of real/ unreal space. Particular attention is paid to the usual and occasional differential nouns with connotative meaning, which are actively used in the language of the Ukrainian press. Usually diverse nouns with connotative meaning include actively used, productively functional lexical units. Occasionally differential nouns with connotative meaning are those that are divided into lexical ones, in which the new form and content of the token are represented, and semantic ones, which are characterized by a new content, and the form remains unchanged. Identifying the meaning of lexically and semantically occasional nouns with connotative expression is possible due to: 1) subtextual potentiality, which helps to reveal the essence and specificity of connotative meaning; 2 ) associative reactions that encourage the creation of a figurative picture of the world and explication of the semantic potential of connotatively expressed tokens; 3 ) textual components that serve to express and transfer semantic potential connotative expression and can stand in the preposition or postposition according to the analyzed word; 4) quotation marks that perform the function of distinguishing the semantic load of the token in certain contextual situations; 5) semantic modifications, characterized by a change in meaning in the information contextual plane, which reveals the connotative potential of the analyzed word. Lexically and semantically occasional nouns with connotative meaning in the language of the Ukrainian press focus and emphasize innovations that occur in all spheres of life.
\end{abstract}

Постановка проблеми. У сучасній інноваційній лінгвістичній площині явище конотації розглядається як у зарубіжному, так і у вітчизняному науковому обігу. Аналізуючи конотацію як лексико-семантичне явище, можна виокремити їі специфічну неоднозначність тлумачення, складну компонентну структуру, різноаспектну семантичну потенційність, функціональну природу тощо. Експлікація лексично та семантично оказіональних іменників 3 конотативним увиразненням у мові української преси набуває актуального значення у мовознавчому просторі.
Мета і завдання статті. Провідною метою даної розвідки є виявлення конотативного потенціалу у лексично та семантично оказіональних іменниках, дати характеристику їх значеннєвої палітри. Реалізація зазначеної мети передбачає такі завдання: розглянути специфічні особливості явища конотації, здійснити семантичний аналіз лексично та семантично оказіональних іменників 3 конотативним увиразненням у мові української преси, описати способи експлікації конотативного потенціалу аналізованих лексем.

Предмет та об'єкт дослідження. Об'єктом дослідження є іменники, що функціонують у мові 
української періодики, а предметом - лексично та семантично оказіональні іменники 3 конотативним забарвленням.

Аналіз останніх досліджень і публікацій. У різні часи конотацію розглядали у своїх роботах такі науковці, як Ю. Апресян, В. Іващенко, Є. Кузнєцова, Ж. Колоїз, Л. Мацько, О. Мироненко, Є. Отін, В. Телія, В. Шаховський та інші, які у своїх наукових розвідках сконцентрували увагу на історичному ракурсі явища конотації, їі структурній специфіці, значеннєвій парадигмі тощо.

Виклад основного матеріалу дослідження. Як свідчать наукові джерела, конотація як лінгвістичний феномен характеризується семантичною сутністю, що узуально чи оказіонально структурована у семантиці мовних одиниць, а також репрезентує емотивно-оцінне і стилістично забарвлене відношення суб'єкта мовлення до дійсності при іiі функціонуванні у висловлюванні, що отримує на основі цього інформаційного навантаження експресивний ефект [4, с. 5]. Внутрішній семантичний потенціал номінативних лексем, реагуючи на зовнішні парадигматичні особливості, розкриває конотативний зміст слова через емотивну, оцінну та стилістичну увиразненість мовних одиниць [4, с. 7].

Дослідниця Є. Кузнєцова конотативний значеннєвий компонент характеризує як допоміжну, соціально важливу інформацію, що базується на провідних елементах оцінного, емоційного та суб' єктивно стилістичного характеру [2, с. 27]. Конотація представлена у роботі вченої у двовимірному ракурсі: 1) вона відображає аксіологічне відношення до денотата, окресленого лексемою, що містить полюси оцінки «+» (позитивна) чи «-» (негативна); 2) вона переплітається із соціальною оцінкою певної мовної одиниці як стилістично обмеженої, діалектної, рідковживаної або спеціальної [2, с. 27]. Вчена зосереджує також увагу на розмежуванні двох пластів лексики - стилістично маркованої та конотативної. Стилістично маркована лексика має зовнішню специфіку і вживається в певному стилі, а конотативний компонент розкривається завдяки внутрішньому потенціалу слова [2, с. 27].

$\mathrm{У}$ наукових роботах В. Харченко зазначено що оцінність, образність, емоційність та експресію у сукупності можна розглядати як конотацію [7, с. 66]. Конотативно виражена лексема базується на таких прагматичних компонентних характеристиках: оцінності, експресії, образності та емоційності, де оцінність передає функціональний ракурс, образність - відображальний, експресія - стилістичний, а емоційність - психологічний спектр [6, с. 48]. Однак не слід забувати про дифузійний характер цих компонентних характеристик та складність чіткого виокремлення кожного зі складників конотації.

Сучасні інноваційні лінгвістичні джерела концентрують увагу на тому, що конотація (від лат. $c o(n)$ - префікс, що означає об'єднання, спільність, сумісність, i notatio - позначення) - це додаткові семантичні і прагматичні особливості (співзначення) лексичного значення та значень інших мовних рівнів, які нашаровуються на предметно-поняттєвий аспект і можуть бути зумовлені як змістовою стороною, так і внутрішньою формою слова [5, с. 278-279].

Аналізуючи феномен конотації, лінгвісти неодноразово звертали увагу й на їі компонентну структуру. Різноплановість тлумачення компонентної характеристики конотації визначається багатовимірними поглядами науковців на специфіку функціонування конотації. На думку О. Мироненко, конотація аргументується чотирикомпонентною структурою: 1) емотивністю, що репрезентує емоційний потенціал суб'єкта щодо певного явища, дії; 2) експресивністю, що свідчить про виражально-зображувальну сутність лексичної одиниці або словосполучення, які відрізняються від нейтральновиражених та надають мовленню образної та емоційної доречності; 3 ) оцінністю, яка виражає позитивну чи негативну оцінку предмета, явища, події; 4) образністю, що служить для передачі асоціативно-образної палітри прагматичного світу [3, с. 187].

Ми вважаємо, що конотативні компоненти можна розглядати як структурно-аналітичні чинники, які в контексті конотативної площини репрезентуються як одне ціле і створюють конотативне тло лексики, та як окремі компонентні складові, що мають взаємопроникну специфіку.

Огляд i аналіз наукових джерел дає змогу зазначати, що конотація функціонує в узуально та оказіонально дифереційних іменниках. Узуально диференційні іменники 3 конотативним увиразненням - це кодовані словниками і активно вживані, продуктивно функціональні лексичні одиниці. Оказіонально диференційні іменники 3 конотативним увиразненням відповідно до структури поділяються на лексичні, що мають нову форму та зміст, та семантичні, що характеризуються новою змістовою наповненістю, а форма у таких словах лишається незмінною. В інноваційному науковому просторі досить актуальним $\epsilon$ питання про лексично та семантично оказіональні іменники з конотативним увиразненням, що функціонують у мові української преси.

Досліджуючи лексично оказіональні іменники 3 конотативним увиразненням, можна виокремити такі шляхи експлікації конотативних значень:

- підтекстові потенційності, що функціонують у дериваційній структурі та допомагають розкрити суть та специфіку конотативного значення слова: Пай-хлопчики: скільки землі продали украӥнці від старту роботи ринку землі (Україна молода). Конотативний іменник пай-хлопчики, де 
перша частина пай асоціюється $з$ ринком купівлі чи продажу земельних паїв, а друга -хлопчики 3 дитиною чоловічої статі, набуває негативного відтінку значення і вказує на володіння людьми земельними ділянками, які вони «незважаючи на скруту, < ..> не квапляться продавати». Смисловий потенціал складного іменника у даному випадку розкривається через переосмислення дериваційної бази лексеми, де пай-хлопчики не можуть здійснювати земельні операції через те, що не вистачає досвіду роботи у цій галузі;

- текстові компоненти, які служать для вираження та передачі семантичного потенціалу іменників 3 конотативним увиразненням та можуть стояти у препозиції чи постпозиції до аналізованого слова: «Противники реформи назвали документ "Ханституцією» через дуже широкі повноваження, які отримував глава держави», - зазначає RFI (Україна молода). Семантичний потенціал оцінно-конотативного іменника ханституція розкривається у контекстній ситуації шляхом звернення до структурних засобів, що допомагають розкрити значення. Слово ханституція утворилося шляхом злиття двох іменників хан+Конституиія та набуло негативного відтінку значення, оскільки в контексті $€$ такі компоненти: «противники реформи назвали <..> через дуже широкі повноваження», які допомагають розкрити таке інформаційне навантаження лексеми: «документ, що вказує на необмежену владу певної особи»;

- асоціативні реакції, що спонукають до створення образної картини світу та експлікації семантичного потенціалу конотативно вираженої лексеми: у назві статті «Поетолікар» вжито конотативно виражений іменник, що утворився шляхом основоскладання 3 двох слів поет та лікар, які асоціюються $з$ духовним лікуванням осіб. У контекстній площині розповідається про те, що Степан Руданський був не тільки майстром поетичного слова, а й професійним лікарем. У періодичному виданні іменник поетолікар набув такої позитивної конотації: «особа, що лікує душі людські».

Виокремлюючи семантично оказіональні іменники 3 конотативним увиразненням, можна виділити такі шляхи експлікації конотативних значень:

- використання лапок, що виконують функцію розрізнення семантичного навантаження лексеми у певних контекстних ситуаціях: Хто породив коронавірус? Докази «батьківства» Китаю побачили «П'ятеро очей» (Україна молода). У ВТССУМ лексема батьківство тлумачиться як «кровна спорідненість між батьком і його дитиною» [1, с.64]. У фактичному матеріалі іменник батьківство набуває негативного значення, вказуючи на походження, виникнення вірусу, який має свої витоки 3 лабораторії китайського міста Ухань;
- семантичні модифікації, що характеризуються зміною значення у інформаційній контекстуальній площині, де розкривається конотативний потенціал аналізованого слова: 1. Водночас почали говорити про небезпеку нового итаму «корони» під назвою «Дельта». «Українська влада має негайно обмежити міграційні потоки зі Сходу, аби запобігти спалаху індійського різновиду небезпечного вірусу», - з таким закликом до керівництва краӥни звернулася Національна академія наук України (Україна молода). У ВТССУМ лексема корона тлумачиться так: 1) металевий 3 коштовними прикрасами вінець, що його носять на голові монархи як символ влади. // Зображення такого вінця на гербах, орденах і т. ін. // Те, що своїм виглядом нагадує такий вінець; 2) влада монарха. // Держава, уряд, влада (у 2 знач.); 3) світлий ореол навколо Сонця, який видно під час сонячного затемнення; 4) те саме, що крона; 5) верхні кінцеві відростки на рогах в літнього оленя $[1$, с. 576]. У контексті конотативно виражений іменник корона утворився від слова коронавірус шляхом усічення частини слова та набув нового значення: «вірус, що спричиняє запалення верхніх дихальних шляхів, бронхів». 2. Володіння иілим "букетом» чемпіонських поясів - иее не тільки яскраво та красиво, а й обтяжливо. Правила боксерських організацій передбачають обов'язковий захист трофеїв (Україна молода). У ВТССУМ лексема букет тлумачиться так: 1) пучок зірваних або зрізаних і складених докупи квітів; 2) сукупність ароматичних і смакових властивостей, характерних для певних сортів продуктів; 3) кущик молодих рослин [1, с. 101]. Однак наведений ілюстративний матеріал свідчить, що інформаційний потенціал даного іменника розширився. У контексті лексема букет завдяки семантичній модифікації набуває такого позитивного конотативного значення: «сукупність, розмаїття».

Висновки і перспективи подальших розробок. Проаналізувавши лексично та семантично оказіональні іменники 3 конотативним значенням, можна сказати, що їх семантичний потенціал розкривається у текстовій площині завдяки контекстуально ситуативним лексемам, асоціативним реакціям, семантичним модифікаціям тощо. Функціонуючи у мові української преси, лексеми передають аксіологічні, культурологічні, політичні тощо зміни, що відбуваються у суспільстві. Усе актуальнішим постає питання розрізнення конотативних значень у лексично та семантично оказіональних іменниках, що набувають різних семантичних особливостей. У подальших дослідженнях плануємо розглянути конотацію лексично та семантично оказіональних слів у творах сучасних українських письменників. 


\section{ЛІТЕРАТУРА}

1. Великий тлумачний словник сучасної української мови / уклад. і голов. ред. В.Т. Бусел. К. ; Ірпінь : ВТФ «Перун», 2009. 1736 с.

2. Кузнецова Э.В. Лексикология русского языка. М. : Высшая школа. 1989. 216 с.

3. Мироненко О.В. Лексико-семантична категорія конотації у проєкції на прислівникові слова. Молодий вчений. Херсон : Видавничий дім «Гельветика», 2016. Ч. II. № 10 (37) жовтень. С. 186-189.

4. Телия В.Н. Коннотативный аспект семантики номинативных единиц. М. : Наука, 1986. 144 с.

5. Українська мова. Енциклопедія / редкол.р: Русанівський В.М., Тараненко О.О., Зяблюк М.П. та ін. 3-тє вид., зі змінами і доп. К.р: Вид-во «Укр. енцикл.» ім. М.П. Бажана, 2007. $856 \mathrm{c}$.

6. Харченко В.К. Взаимодействие коннотативных признаков, созначений в семантике слова. Лексические и грамматические компоненты в семантике языкового знака: межвуз. сб. науч. тр. Воронеж : Изд-во Воронеж.ун-та, 1983. C. $47-52$.

7. Харченко В.К. Разграничение оценочности, образности, экспрессии и эмоциональности в семантике слова. Русский язык в школе. 1976. № 3. C. 66-71.

8. Юрченко Т.Г. Оказіоналізми у творчості Павла Загребельного: структурно-семантичний і стилістичний аспекти : автореф. дис. ... канд. філол. наук : 10. 02.01 ; НАНУ, Ін-т української мови. К., 2003. 19 с.

\section{REFERENCES}

1. Busel, V.T. (2009) Large explanatory dictionary of the modern Ukrainian language [Velykyy tlumachnyy slovnyk suchasnoyi ukrayinskoyi movy]. K.; Irpen : VTF "Perun", 1736 p.

2. Kuznetsova, E.V. (1989) Lexicology of the Russian language [Leksikologiya russkogo yazyka]. M. : Higher school. 1989. 216 p.

3. Mironenko, O.V. (2016) The lexico-semantic category of the connotation in the projection on the hereditary words [Leksyko-semantychna katehoriya konotatsiyi u proektsiyi na pryslivnykovi slova]. Molodiy vchenii: Naukovyi zhurnal. Kherson, part II, №. 10, pp. 186-189.

4. Telia, V.N. (1986) Connotative aspect of semantics of nominative units [Konnotatyvnyy aspekt semantyky nomynatyvnykh edynyts]. M. : Nauka, 144 p.

5. Ukrainian language. Encyclopedia (2007) [Ukrayin ska mova. Entsyklopediya] / Editor: Rusanivsky V.M., Taranenko O.O., Zyablyuk M.P. etc. 3rd ed., with changes and add. K.: Publishing house "Ukr. encyclopedia" them. M.P. Bazhana, $856 \mathrm{p}$.

6. Kharchenko, V.K. (1983) Interaction of connotative features, meanings in the semantics of the word [Vzaimodeystviye konnotativnykh priznakov, soznacheniy $\mathrm{v}$ semantike slova]. Lexical and grammatical components in the semantics of a language sign: Interuniversity sat scientific tr. Voronezh, pp. 47-52.

7. Kharchenko, V.K. (1976) Differentiation of evaluativeness, imagery, expression and emotionality in the semantics of the word [Razgranicheniye otsenochnosti, obraznosti, ekspressii i emotsional'nosti v semantike slova]. Russian language at school, № 3, pp. 66-71.

8. Yurchenko, T.G. (2003) Occasionalism in the works of Pavel Zagrebelny [Okazionalizmy $\mathrm{u}$ tvorchosti Pavla Zahrebelnoho]. Structuralsemantic and stylistic aspects: author. dis. ... Cand. Philol. Sciences. K., 19 p. 